\title{
Adult human mesenchymal stromal cells and the treatment of graft versus host disease
}

REVIEW

\section{Richard P Herrmann Marian J Sturm}

Cell and Tissue Therapies, Western Australia, Royal Perth Hospital, Wellington Street, Perth, WA, Australia
Correspondence: Marian Sturm CTTWA, Level 2, North Block, Royal Perth Hospital, Wellington Street, Perth, WA, 6000, Australia Email marian.sturm@health.wa.gov.au
This article was published in the following Dove Press journal:

Stem Cells and Cloning:Advances and Applications

28 February 2014

Number of times this article has been viewed
Abstract: Graft versus host disease is a difficult and potentially lethal complication of hematopoietic stem cell transplantation. It occurs with minor human leucocyte antigen (HLA) mismatch and is normally treated with corticosteroid and other immunosuppressive therapy. When it is refractory to steroid therapy, mortality approaches $80 \%$. Mesenchymal stromal cells are rare cells found in bone marrow and other tissues. They can be expanded in culture and possess complex and diverse immunomodulatory activity. Moreover, human mesenchymal stromal cells carry low levels of class 1 and no class 2 HLA antigens, making them immunoprivileged and able to be used without HLA matching. Their use in steroid-refractory graft versus host disease was first described in 2004. Subsequently, they have been used in a number of Phase I and II trials in acute and chronic graft versus host disease trials with success. We discuss their mode of action, the results, their production, and potential dangers with a view to future application.

Keywords: mesenchymal stromal cells, graft versus host disease, acute, chronic

\section{Introduction}

Graft versus host disease (GVHD) is, simplistically, the attack of a transplanted donor's immune system against the recipient's immune system, usually after allogeneic bone marrow transplantation but occasionally after homologous blood transfusion. ${ }^{1}$

The history of GVHD possibly dates back to an observation in 1916 by Murphy of a nodule forming on chicken embryos injected with cells from an adult bird. ${ }^{2}$ It was not till much later that this was interpreted as an immune reaction by the chicken to the foreign cells. $^{3}$ Mice injected with foreign cells died of what we would now call acute GVHD, and a smaller number developed a syndrome of chronic GVHD, known at the time as "runt disease". ${ }^{4}$ The first human marrow transplants were reported in 1957 but, in the absence of knowledge of the human leucocyte antigen (HLA) system at that time, transient engraftment was seen in only one patient. ${ }^{5}$ Progress was slow, and when Bortin reported on 200 patients who had received bone marrow transplants, none were successful. ${ }^{6}$

As our knowledge of the HLA system has developed, matching between donor and recipient has improved and allowed the development of multiple national registries of donors unrelated to recipients, facilitating better matching and reducing the risk of acute GVHD. ${ }^{7}$

\section{Development of acute GVHD}

Acute GVHD is a donor T lymphocyte-mediated disease. In Billingham's original description, three elements were necessary for its development, ie, the host must 
be incapable of rejecting the graft, the graft must contain immunocompetent cells, and there must be incompatibilities in transplantation antigens between donor and host. ${ }^{8}$ To this list has been added a fourth requirement, ${ }^{9}$ ie, that the effector cells must migrate to the target tissues. Several findings emphasize the need for homing of the effector cells to the target tissues, usually skin, liver, and gut. The involved target tissue demonstrates a lymphocytic infiltration, even when the patient is lymphopenic from immunosuppression.

\section{Clinical features of acute GVHD}

After standard high-dose chemotherapy and/or total body irradiation "conditioning" of the recipient, the purpose of which is to immune-ablate the recipient and often to near totally ablate the potential tumor load residual in the recipient, the recipient receives hematopoietic stem cells collected ("harvested") from the donor's bone marrow, or more commonly, from the primed peripheral blood. Alternatively, the donor source may be stored umbilical cord blood.

Typically the onset of acute GVHD is 21-28 days after transplantation, but may be considerably later if lower dose conditioning is used. The organs most commonly affected are the skin, liver, and gastrointestinal tract. The involvement of other organs is controversial. ${ }^{10}$ Acute GVHD is graded on severity as a guide to prognosis and also to allow uniform interpretation of clinical trial data regarding treatment outcomes. Many centers use the 1994 consensus conference grading classification. ${ }^{11}$

The skin signs are usually of a maculopapular rash which may become confluent and often involves the palms and soles, which is a useful clue given that this is uncommon with drug and other types of rashes. Severe skin involvement can cause life-threatening exfoliative dermatitis, and management requires a team approach with dermatologists and burns specialists.

Liver involvement is graded on bilirubin, and liver function tests show a variable pattern with a wide differential diagnosis. Involvement of the upper gastrointestinal tract produces predominantly nausea and vomiting, and lower gastrointestinal involvement is characterized by profuse diarrhea which is bloody when there is severe involvement, again with a wide differential diagnosis.

Biopsy of the affected organ has been the most reliable diagnostic tool, but because of the risk, liver biopsy is not usually performed. Searches have been made for changes in the plasma proteins ("biomarkers") involved in the pathophysiology of acute GVHD which might be of diagnostic use and identify patients whose acute GVHD will progress. A wide spectrum of plasma proteins has been tested and are still being validated for their utility as biomarkers. ${ }^{12}$ Currently diagnosis of acute GVHD relies on tissue biopsies in practice and in clinical trials of new therapies.

\section{Treatment of acute GVHD}

Immunosuppression with corticosteroids is the primary preferred form of therapy in acute GVHD. A response was seen in $55 \%$ in one large series of 443 patients but a durable response was maintained in only $35 \% .{ }^{13}$ This level of response is typical of that seen in clinical practice. The prognosis for patients refractory to corticosteroid therapy is poor, with approximately $30 \%$ alive at one year. ${ }^{14} \mathrm{~A}$ recently published meta-analysis of steroid-refractory graft disease concluded that no one treatment was better than another, ${ }^{15}$ and the American Society of Blood and Marrow Transplantation has made recommendations for the primary and secondary management of acute GVHD, concluding similarly that no one treatment is preferred for steroid-refractory GVHD, emphasizing the need for well-designed clinical trials with adequate follow-up. ${ }^{16}$

\section{Graft versus leukemia effect}

It was appreciated in animal experiments early on that GVHD in an animal led to a lower leukemic relapse rate, and an analysis of transplants in man first showed a lower relapse rate of 2.5-fold when those with GVHD were compared with those without GVHD. ${ }^{17}$ One of the holy grails of marrow transplantation is to preserve the antileukemic effect but abrogate GVHD. The history of this search was summarized elegantly by Truitt in the Mortimer M Bortin lecture of $2004 .{ }^{18}$ At this time, it remains an elusive goal despite intense research at both the basic and clinical trial levels. There are two classes of cell responsible for the antileukemic effect, ie, the donor $\mathrm{T}$ lymphocyte and the natural killer cell.

\section{Chronic GVHD}

In the past, chronic GVHD was thought of as an extension of the acute GVHD process beyond 100 days, and it was assumed that the same immunomodulatory measures applied to acute GVHD were appropriate. Chronic GVHD has some features of autoimmune disease. There is evidence that the pathogenesis of chronic GVHD is different from that of acute GVHD. ${ }^{19}$ In a mouse model of chronic GVHD, which has clinical features similar to those of chronic GVHD in humans, $\mathrm{T}$ cells that escaped from negative thymic selection caused chronic GVHD and could be adoptively transferred, 
causing chronic GVHD in recipient mice. The investigators suggest that improving thymic function may be advantageous in preventing chronic GVHD. ${ }^{20}$

A National Institutes of Health consensus document has sought to clarify the classification and included recognition of acute GVHD occurring beyond 100 days and also recognition of an overlap syndrome that has features of both acute and chronic GVHD. ${ }^{21}$ Chronic GVHD can develop either as an extension of acute GVHD or develop spontaneously without prior acute GVHD. Chronic GVHD is a complex syndrome with variable multiple organ involvement, carrying significant patient morbidity and mortality. ${ }^{22}$

Chronic GVHD can involve predominantly one organ or many. Manifestations include lichenoid and dry mouth syndromes from salivary gland infiltration and ultimately fibrosis, with late intraoral squamous cell carcinoma, ${ }^{23}$ keratoconjunctivitis and dry eye syndromes, obliterative bronchiolitis in the lung, liver dysfunction, skin, hair and nails with pigmentation and depigmentation, dystrophic nail changes, sclerodermatous-like changes, and female genital changes with ulceration, strictures, and cellular atypia. Ongoing changes to these organs ultimately result in fibrosis and progressive functional deterioration. For a comprehensive discussion of the features of chronic GVHD, see Filipovich. ${ }^{24}$

\section{Mesenchymal stromal cells}

Mesenchymal stromal cells (MSCs) are multipotent adult cells capable of differentiating down multiple mesenchymal lineages. They are adherent fibroblastoid-like cells with an extensive capacity for expansion. They reside within the connective tissue of most organs, and have been isolated from bone marrow, placenta, adipose tissue, umbilical cord, amniotic fluid, circulating blood, various fetal tissues, skeletal muscle synovium, dental pulp, liver, spleen, lung, and dermis. Their essential identifying criteria were defined by a committee of the International Society of Cell Therapy as:

- adherence to plastic in culture

- expression of CD73, CD105, and CD90, and lack of expression of CD45, CD34, CD14 or CD11b, CD79alpha or CD19, and HLA-DR surface molecules

- an ability to differentiate into osteoblasts, adipocytes, and chondrocytes in vitro. ${ }^{25}$

MSCs in man (unlike the mouse) are not immunogenic and fail to stimulate allogeneic lymphocytes. ${ }^{26}$ Rather, they suppress proliferation of both $\mathrm{T}$ and $\mathrm{B}$ lymphocytes in a dosedependent manner. ${ }^{27,28}$ They escape recognition by alloreactive $\mathrm{T}$ cells and natural killer cells. They have low levels of
HLA class I expression and no expression of HLA class II antigens. ${ }^{26}$ Mouse MSCs possess class II HLA antigens, and outcomes of preclinical trials in the mouse cannot be applied to humans. ${ }^{29}$ Human MSCs do not express costimulatory molecules and are unable to induce a T cell-mediated immune response. Hence, in transplantation, there is no need for matching donor to recipient. MSCs also inhibit the cytotoxicity of natural killer cells as well as macrophages and dendritic cells. ${ }^{30}$ Most work has focused on MSCs derived from bone marrow; however, there are also some clinical reports using MSCs derived from adipose tissue or placental tissue, and studies have shown they may function well in clinical use. ${ }^{31}$ MSCs from different sources may not always be functionally equivalent or exhibit the same differentiation potential.

Four main functions have been recognized for bone marrow-derived MSCs, and are reviewed by Uccelli et al: ${ }^{32}$

- MSCs constitute the connective tissue scaffolding of the bone marrow

- MSC support hemopoiesis by secretion of cytokines, chemokines, and growth factors, promote cell interactions by providing a niche, and drive proliferation, expansion, and differentiation of hemopoietic cells

- MSCs are able to differentiate into different cell types

- MSCs have immunosuppressive and immunoregulatory properties.

There is much interest in the immunomodulatory properties of MSCs, and they have been found to act at multiple levels involving many factors. Through cytokines, chemokines, and Toll-like receptors, MSCs exert their effect on most cells of the immune system and inhibit the proliferation, activation, and cytokine release of T cells, B cells, dendritic cells, and natural killer cells. These qualities have seen their application to GVHD associated with allogeneic hematopoietic stem cell transplantation, with promising outcomes for this serious condition.

\section{Manufacture of MSCs}

In most of the clinical trials published and in all GVHD trials, bone marrow-derived MSCs have been expanded in culture. They have also been harvested from adipose tissue, umbilical cord blood, and other tissues. ${ }^{33}$ These cells are rare in marrow, representing $0.001 \%-0.1 \%$ of all nucleated cells, ${ }^{34}$ but the cells are readily isolated from other marrow cells by their ability to adhere to plastic. Traditionally fetal bovine serum has been used as a source of the necessary growth factors for cell expansion, but immune responses in a recipient can cause failure of therapeutic effect. ${ }^{35,36}$ One substitute that has proven useful and allowed expansion of MSCs is human 
platelet lysate, a good source of growth factors. ${ }^{37,38}$ The cell yield on expansion is also influenced by donor age and with marrow harvesting procedures. ${ }^{39}$

Protocols vary enormously in different laboratories and the outcome is not a uniform product that can be easily compared between laboratories. Each laboratory needs to establish its optimal protocol for culture expansion and passaging of cells. For clinical use, factories may be employed as otherwise a large number of flasks are needed. Bioreactors are being developed with a view to scaling up production, and cells need to be expanded under good manufacturing conditions with a view to licensing by the relevant regulatory authorities in the country of production. ${ }^{40,41}$

MSCs need to be characterized in several ways. Flow cytometry to characterize the surface antigens should be done and their ability to differentiate down adipogenic, chondrogenic, and osteogenic pathways confirmed according to criteria promulgated by the International Society of Cellular Therapy. ${ }^{25}$ Recognizing the increasing realization of the immunologic properties of MSCs, the MSC Committee of the International Society for Cellular Therapy has recently published a discussion paper on immunological characterization of MSCs for clinical use. ${ }^{42}$ In this thoughtful paper, the authors make a number of suggestions for comprehensive assessment of regulatory response. These include a standard immune plasticity assay using interferon gamma as a priming agent, interrogating the indoleamine deoxygenase response as part of such a "licensing" assay, and the use of functional assays in assessing immune suppression activity. The authors advise caution in relying on xenotransplantation models as being applicable to humans, and suggest prospective analysis of lymphocyte populations in treated patients as well as monitoring to determine whether the injected MSCs are the target of an immune response.

\section{Safety and quality issues}

Safety can be considered at the manufacture/production level, then at the clinical use level.

Manufacture under good manufacturing practice conditions is important in prevention of contamination of the product with microorganisms. The donor must be screened for infectious agents as well as for any tissue or blood donation. Cultures are ideally in a closed environment, but in reality, mostly they are not. The development of effective bioreactors will be an important development in maintaining sterility.

The harvesting of cells for therapeutic use before they reach a senescent stage is considered important because of the potential risk of malignant transformation in culture through many passages. ${ }^{43,44}$

Because of the immunomodulating effect of MSCs, it might be reasonable to expect they could induce a malignancy in the recipient or a recurrence of the treated hematologic malignancy in a bone marrow transplant recipient treated with MSCs, but the trials reviewed in this report do not report such an increase, although it must be stated that the numbers are small. An autopsy and tissue study in patients who had received MSCs for steroid-refractory acute GVHD did not find any evidence of MSC-related malignancy nor ectopic bone formation. ${ }^{45}$

A further risk in use of MSCs for GVHD is compounding the risk of opportunistic infection in an already heavily immune-deficient host. Whilst the numbers are small, this appears not to be the case, at least for viral infection. ${ }^{46}$ A German group has published an intriguing in vitro study of the antimicrobial effect of human and murine MSCs. ${ }^{47}$ They found that cytokine-activated human MSCs exhibited a broad effect against some bacteria, reducing the growth of Staphylococcus aureus, Staphylococcus epidermidis, and Enterococcus faecium. They further showed that this effect was related to indoleamine dioxygenase production with tryptophan and was reversed by addition of 1-MT, a tryptophan inhibitor. Murine MSCs do not produce indoleamine deoxygenase but do produce nitric oxide, and no antibacterial effect was seen. After infection of human MSCs with the intracellular parasite Toxoplasma, it was found by these authors that activation of MSCs by interferon gamma suppressed growth of Toxoplasma. Interferon gamma-activated MSCs also suppressed growth of cytomegalovirus.

\section{Autologous or allogeneic MSCs?}

Whilst the use of autologous MSCs may be thought more desirable, none of the published trials in GVHD have employed autologous cells. The reasons for this are fear of transmitting tumor cells from the hematologic malignancy being treated back to the recipient and the concern that prior cytotoxic chemotherapy may have damaged the cells. MSC use in other trial areas has, on occasion, used autologous cells but again, the disease state being treated may be associated with defective MSCs. ${ }^{48}$

Further, there may not be time to wait the $6-8$ weeks required to culture significant cells for clinical use. The ability to use nonimmunogenic and immune-privileged allogeneic MSCs as an "off the shelf" treatment is often a factor when treatment need is urgent. MSCs appear not to elicit an HLA-antibody response, but components of the culture medium such as fetal calf serum may do so and render 
subsequent MSC infusions ineffective. ${ }^{35}$ The ability to make multiple doses of cells from one donor sample is also cheaper because MSC therapy is, by the nature of production and requisite testing, an expensive process.

\section{Use in acute GVHD}

The first report of the use of human MSCs was published by Le Blanc et al in 2004. ${ }^{49}$ They infused repeated doses of haploidentical bone marrow-derived MSCs into a young boy with severe acute GVHD after a bone marrow transplant and obtained a strikingly good response. The mortality of steroid-refractory acute GVHD is very high, in the order of $80 \%$, and second-line therapies have not shown a significant improvement in outcome. ${ }^{14}$

Most of the subsequent trials of MSCs in acute GVHD have been in steroid-refractory disease, and the published trials are listed in Table 1. The largest trial was the collaborative European study which found a significant response rate and a beneficial effect on mortality. The MSCs were of HLA identical, haploidentical, and third party origin. Response bore no relationship to HLA match and, importantly, complete response was an important positive predictor of improved survival. It was noted that the MSC infusions were tolerated well, and there did not appear to be increased rates of infection or hematological malignancy compared with the expected rate in this very heavily immune-suppressed population..$^{50}$

It is not possible to make any comparisons between the studies listed in Table 1 because of the variable preparation, dosing, and frequency of MSC infusions. Further, there are no standardized potency assays to assess the efficacy of these cells in vitro. Most trials indicate a positive response without safety issues being identified. However, a commercially sponsored, randomized Phase III study in steroid-refractory acute GVHD (NCT00366145) ${ }^{51}$ apparently did not reach significance in its primary objective, failing to show a difference in complete response in those receiving MSCs. This study has not been formally published and raises questions as to why the outcome was different to the studies summarized in Table 1. The issues have been discussed in a review by Galipeau, who suggests a number of possibilities ${ }^{52}$ whereby industrially produced cells may differ from smaller batches produced in academic institutions. These include donor variance, culture differences, expansion pressures and volumes, possible differences in immunogenicity from expansion, and possible deleterious effects of cryopreservation. Generally, with malignant hematological disorders, autologous MSCs have not been employed for fear of transmitting malignant cells back to the recipient, but it must be remembered that the proliferation ability and activity declines with age and may also be affected by the underlying disease process. ${ }^{48}$

There have been fewer studies using MSCs as prophylaxis to prevent (rather than treat) acute GVHD. A randomized Russian study using MSCs from the transplant donor given to the recipient when the leukocyte count recovered to $1 \times 10^{9} / \mathrm{L}$ showed a significantly lower rate of acute GVHD in the MSC group compared with the control group not given MSCs, but had no effect on the rate of chronic GVHD. ${ }^{53}$ In a prophylactic setting, timing of administration of MSCs may be critical. It has been shown that activation of MSCs by interferon gamma is an important process resulting in production of the immunosuppressive indoleamine 2,3- dioxygenase by these cells, and that interferon gamma is upregulated by acute GVHD. ${ }^{54-56}$

\section{Use in chronic GVHD}

There have been fewer, smaller studies in chronic GVHD (Table 2). Unsurprisingly, the responses have been lower

Table I Mesenchymal stromal cell trials in acute graft versus host disease*

\begin{tabular}{|c|c|c|c|c|c|c|c|c|}
\hline Authors & Phase & $\mathbf{n}$ & Dose & CR (\%) & PR (\%) & NR (\%) & OS & Donor source \\
\hline Ringden et $a^{65}$ & $\mathrm{I}$ & 8 & Variable & $6(75)$ & - & $2(25)$ & $52-3$ years & $\begin{array}{l}2 \text { HLA ID siblings, } \\
6 \text { haploidentical family } \\
\text { members }\end{array}$ \\
\hline Fang et $\mathrm{al}^{66}$ & I & 6 & $\mathrm{I} \times 10^{6} / \mathrm{kg} \times \mathrm{I}$ & $5(83)$ & - & I (16.7) & 440 months & Third party \\
\hline Le Blanc et $\mathrm{al}^{50}$ & 2 & 55 & Variable & $30(54.5)$ & $9(16.40)$ & $16(29.1)$ & $\begin{array}{l}52 \% \text { for } C R \\
16 \% \text { for } P R, N R\end{array}$ & Third party \\
\hline Von Bonin et $\mathrm{al}^{67}$ & I & 13 & $0.9 \times 10^{6} / \mathrm{kg} \times 2$ & $2(15)$ & $5(38)$ & $6(46)$ & $31 \%$ at 257 days & Third party \\
\hline Kebriaei et $a^{68}$ & 2 & 31 & 2 versus $8 \times 10^{6} / \mathrm{kg} \times 2$ & $24(77)$ & $5(16)$ & $2(6.5)$ & NS & Third party \\
\hline Perez-Simon et $\mathrm{al}^{69}$ & 1 & 10 & $2 \times 10^{6} / \mathrm{kg} \times$ variable & I (I0) & $6(60)$ & $3(30)$ & $20 \%$ at final follow-up & Various \\
\hline Herrmann et $\mathrm{al}^{63}$ & 1 & 12 & $2 \times 10^{6} / \mathrm{kg} \times 2-4$ & $7(58)$ & $4(38)$ & $3(30)$ & $55 \%$ at 36 months & $\begin{array}{l}\text { Haploidentical family } \\
\text { members or third party }\end{array}$ \\
\hline Muroi et $\mathrm{al}^{70}$ & I & 14 & $2 \times 10^{6} / \mathrm{kg} \times 8$ & $12(86)$ & I (7) & I (7) & $57 \%$ at 24 months & Third party \\
\hline
\end{tabular}

Notes: *Published trials of mesenchymal stromal cells in acute graft versus host disease in peer-reviewed journals. Compassionate use reports are not included. Abbreviations: NS, not stated; CR, complete response; OS, overall survival; PR, partial response; NR, no response; HLA ID, human leucocyte antigen identical. 
Table 2 Mesenchymal stromal cell trials in chronic graft versus host disease*

\begin{tabular}{|c|c|c|c|c|c|c|c|c|}
\hline Authors & Phase & $\mathbf{n}$ & Dose & CR (\%) & PR (\%) & NR (\%) & OS & Donor BM source \\
\hline Zhang et $\mathrm{al}^{71}$ & I & 12 & Various $\times 3$ & $3(25)$ & $6(50)$ & $3(25)$ & 77.7 at 2 years & Various \\
\hline Weng et $\mathrm{al}^{72}$ & I & 19 & $0.6 \times 10^{6} / \mathrm{kg} \times 1$ & $4(2 I)$ & $10(57.6)$ & $5(28.8)$ & $75 \%(N S)$ & Third party \\
\hline Zhou et $\mathrm{al}^{57}$ & 1 & 4 & $\mathrm{I}-2 \times 10^{6} / \mathrm{kg} \times 4-8$ & 0 & $4(100)$ & 0 & $100 \%$ at $14-23$ months & Third party \\
\hline Perez-Simon et $a^{69}$ & $1 / 2$ & 8 & $2 \times 10^{6} / \mathrm{kg} \times$ variable & $\mathrm{I}(\mathrm{I})$ & $4(37)$ & $4(50)$ & $2 / 8$ at $5-12$ months & Various \\
\hline Herrmann et $a^{63}$ & 1 & 7 & $2 \times 10^{6} / \mathrm{kg} \times$ various & I (I2) & $3(43)$ & $4(57)$ & $50 \%$ at 8 months & Various \\
\hline
\end{tabular}

Note: *Published trials of mesenchymal stromal cells in chronic graft versus host disease in peer-reviewed journals.

Abbreviations: BM, bone marrow; NS, not stated; CR, complete response; OS, overall survival; PR, partial response; NR, no response.

in advanced disease where there are irreversible fibrotic changes. However, there are limited reports in specialized areas which give some encouragement for the use of MSCs. One of the more difficult problems is the development of sclerodermatous changes associated with chronic GVHD and a report suggests a role for MSCs in this situation. ${ }^{57}$ Another distressing problem affecting up to two thirds of patients is the dry eye syndrome, due to infiltration of lacrimal and meibomian glands with lymphocytes ${ }^{41}$ A report outlining the use of MSCs in 22 patients with refractory chronic GHDassociated dry eye syndrome showed subjective and objective responses in 12 patients. ${ }^{58}$ Interestingly, these authors found an increase of CD8+CD28-regulatory cells in the responding group but no change in $\mathrm{CD} 4+\mathrm{CD} 25+$ regulatory $\mathrm{T}$ cells.

\section{Discussion}

Most of the published trials have reported a favorable effect in acute GVHD, but no randomized Phase III trial has yet been published, although one is underway in Europe. Steroidrefractory acute GVHD has a poor outlook, so these Phase II trials are encouraging, but randomized Phase III trials should be more conclusive and long-term follow-up will be needed. With chronic GVHD, the patient group is more heterogeneous; however, results are encouraging if more variable. Earlier treatment in both acute GVHD and chronic GVHD is likely to be more beneficial and trials are awaited.

In general, MSC infusions are well tolerated and none of the published reports have shown an adverse safety effect, but again, longer-term follow-up is needed to be more certain of this. Initial trials were concerned with abnormal tissue formation such as ectopic bone but this has not proved to be a problem in practice. Late malignancy has also been a concern but there is as yet no proof of this in clinical trial use. ${ }^{59}$ Nonetheless, it is prudent to use MSCs that have not been cultured through many passages as chromosomal changes leading to malignancy are possible but not shown in man.

The donor source has also been of potential concern. The use of autologous MSCs could transmit the underlying hematological malignancy back to the recipient.
Efficacy has apparently not depended on whether HLAmatched haploidentical or third party donor cells were used. ${ }^{50}$ The age and gender of the donor may be a cause of variability in growth potential as well as the culture conditions, such as choice of media and seeding density. 39,60

\section{Conclusion}

In the decade since the landmark first case report of a boy given haploidentical MSCs for refractory acute GVHD, ${ }^{49}$ much has been achieved using MSCs for steroid-refractory acute GVHD, but there are as yet no published data from Phase III trials and many other questions remain. It is generally thought that MSCs act in a paracrine fashion and do not engraft ("hit and run") after being attracted under chemokine gradients to sites of inflammation. ${ }^{61,62}$ It is not known whether MSCs of different tissue origins act in differing degrees of efficacy in clinical use, whether MSCs prepared in differing manufacturing facilities differ in their potency, ${ }^{52}$ what is the right dose to use for a given clinical scenario and how durable the action is, and indeed whether MSCs from different manufacturing facilities have different durations of action. It is the current authors' experience using MSCs in different clinical trial scenarios that maintenance therapy ability should be integral to future clinical trials to determine the longer-term place of MSCs in immunomodulation and tissue repair. ${ }^{63,64}$

As heterogeneous as acute GVHD is in its clinical presentations and outcome, chronic GVHD is more so, and the clinical trial data (Table 2) reflect that fact. The end result of chronic GVHD in causing irreversible tissue fibrosis makes the consideration of timely intervention using MSCs at an earlier stage of chronic GVHD an important consideration, but the heterogeneity of chronic GVHD makes the design of a randomized trial difficult.

All of the trials listed have shown a response rate that is probably greater than that of current treatment, and randomized studies with adequate follow-up are awaited to confirm these findings. A follow-up of 6 months is suggested in the recommendations of the American Society of Blood and Marrow Transplantation. ${ }^{16}$ 


\section{Acknowledgments}

The authors acknowledge the support received from the Ray and Bill Dobney Foundation, the Medical Research Foundation, Royal Perth Hospital, and the Research Infrastructure Support Services in funding our clinical trials of MSCs in GVHD.

\section{Disclosure}

The authors state there are no conflicts of interest in this work.

\section{References}

1. Ruhl H, Bein G, Sachs UJ. Transfusion-associated graft-versus-host disease. Transfus Med Rev. 2009;23:62-71.

2. Murphy J. The effect of adult chick organ graft on the chick embryo. J Exp Med. 1916;24:1-6.

3. Simonsen M. The impact on the developing embryo and newborn animal of adult homologous cells. Acta Pathol Microbiol Scand. 1957;40: 480-500.

4. Billingham RE, Brent L. Quantitative studies on tissue transplantation immunity. IV. Induction of tolerance in newborn mice and studies on the phenomenon of runt disease. Phil Trans R Soc B Biol Sci. 1959;242:439.

5. Thomas ED, Lochte HL Jr, Lu WC, Ferrebee JW. Intravenous infusion of bone marrow in patients receiving radiation and chemotherapy. N Engl J Med. 1957;257:491-496.

6. Bortin MM. A compendium of reported human bone marrow transplants. Transplantation. 1970;9:571-587.

7. van Rood JJ, Oudshoorn M. Eleven million donors in bone marrow donors worldwide! Time for reassessment? Bone Marrow Transplant. 2008;41:1-9.

8. Billingham RE. The biology of graft-versus-host reactions. Harvey Lect. 1966;62:21-78.

9. Sackstein R. A revision of Billingham's tenets: the central role of lymphocyte migration in acute graft-versus-host disease. Biol Blood Marrow Transplant. 2006;12(1 Suppl 1):2-8.

10. Deeg HJ, Antin JH. The clinical spectrum of acute graft-versus-host disease. Semin Hematol. 2006;43:24-31.

11. Przepiorka D, Weisdorf D, Martin P, et al. 1994 Consensus Conference on Acute GVHD Grading. Bone Marrow Transplant. 1995;15: $825-828$.

12. Paczesny S. Discovery and validation of graft-versus-host disease biomarkers. Blood. 2013;121:585-594.

13. MacMillan ML, Weisdorf DJ, Wagner JE, et al. Response of 443 patients to steroids as primary therapy for acute graft-versus-host disease: comparison of grading systems. Biol Blood Marrow Transplant. 2002;8: 387-394.

14. Deeg HJ. How I treat refractory acute GVHD. Blood. 2007;109: 4119-4126.

15. Martin PJ, Inamoto Y, Flowers ME, Carpenter PA. Secondary treatment of acute graft-versus-host disease: a critical review. Biol Blood Marrow Transplant. 2012;18:982-988.

16. Martin PJ, Rizzo JD, Wingard JR, et al. First- and second-line systemic treatment of acute graft-versus-host disease: recommendations of the American Society of Blood and Marrow Transplantation. Biol Blood Marrow Transplant. 2012;18:1150-1163.

17. Weiden PL, Flournoy N, Thomas ED, et al. Antileukemic effect of graft-versus-host disease in human recipients of allogeneic-marrow grafts. N Engl J Med. 1979;300:1068-1073.

18. Truitt RL. The Mortimer M. Bortin Lecture: to destroy by the reaction of immunity: the search for separation of graft-versus-leukemia and graft-versus-host. Biol Blood Marrow Transplant. 2004;10:505-523.
19. Toubai T, Sun Y, Reddy P. GVHD pathophysiology: is acute different from chronic? Best Pract Res Clin Haematol. 2008;21:101-117.

20. Sakoda Y, Hashimoto D, Asakura S, et al. Donor-derived thymicdependent T cells cause chronic graft-versus-host disease. Blood. 2007;109:1756-1764.

21. Filipovich AH, Weisdorf D, Pavletic S, et al. National Institutes of Health consensus development project on criteria for clinical trials in chronic graft-versus-host disease: I. Diagnosis and staging working group report. Biol Blood Marrow Transplant. 2005;11:945-956.

22. Socie G, Ritz J, Martin PJ. Current challenges in chronic graftversus-host disease. Biol Blood Marrow Transplant. 2010; 16(Suppl 1):S146-S151.

23. Fassil H, Bassim CW, Mays J, et al. Oral chronic graft-vs-host disease characterization using the NIH scale. J Dent Res. 2012; 91(Suppl 7):45S-51S.

24. Filipovich AH. Diagnosis and manifestations of chronic graft-versushost disease. Best Pract Res Clin Haematol. 2008;21:251-257.

25. Dominici M, Le Blanc K, Mueller I, et al. Minimal criteria for defining multipotent mesenchymal stromal cells. The International Society for Cellular Therapy position statement. Cytotherapy. 2006;8:315-317.

26. Le Blanc K, Tammik C, Rosendahl K, Zetterberg E, Ringden O. HLA expression and immunologic properties of differentiated and undifferentiated mesenchymal stem cells. Exp Hematol. 2003;31:890-896.

27. Bocelli-Tyndall C, Bracci L, Spagnoli G, et al. Bone marrow mesenchymal stromal cells (BM-MSCs) from healthy donors and auto-immune disease patients reduce the proliferation of autologous- and allogeneicstimulated lymphocytes in vitro. Rheumatology (Oxford). 2007;46: 403-408.

28. Corcione A, Benvenuto F, Ferretti E, et al. Human mesenchymal stem cells modulate B-cell functions. Blood. 2006;107:367-372.

29. Nauta AJ, Westerhuis G, Kruisselbrink AB, Lurvink EG, Willemze R, Fibbe WE. Donor-derived mesenchymal stem cells are immunogenic in an allogeneic host and stimulate donor graft rejection in a nonmyeloablative setting. Blood. 2006;108:2114-2120.

30. Spaggiari GM, Moretta L. Cellular and molecular interactions of mesenchymal stem cells in innate immunity. Immunol Cell Biol. 2013;91: 27-31.

31. Choudhery MS, Badowski M, Muise A, Harris DT. Comparison of human mesenchymal stem cells derived from adipose and cord tissue. Cytotherapy. 2013;15:330-343.

32. Uccelli A, Moretta L, Pistoia V. Mesenchymal stem cells in health and disease. Nat Rev Immunol. 2008;8:726-736.

33. Malgieri A, Kantzari E, Patrizi MP, Gambardella S. Bone marrow and umbilical cord blood human mesenchymal stem cells: state of the art. Int J Clin Exp Med. 2010;3:248-269.

34. Kemp KC, Hows J, Donaldson C. Bone marrow-derived mesenchymal stem cells. Leuk Lymphoma. 2005;46:1531-1544.

35. Sundin M, Ringden O, Sundberg B, Nava S, Gotherstrom C, Le Blanc K. No alloantibodies against mesenchymal stromal cells, but presence of anti-fetal calf serum antibodies, after transplantation in allogeneic hematopoietic stem cell recipients. Haematologica. 2007;92:1208-1215.

36. Spees JL, Gregory CA, Singh H, et al. Internalized antigens must be removed to prepare hypoimmunogenic mesenchymal stem cells for cell and gene therapy. Mol Ther. 2004;9:747-756.

37. Bernardo ME, Avanzini MA, Perotti C, et al. Optimization of in vitro expansion of human multipotent mesenchymal stromal cells for celltherapy approaches: further insights in the search for a fetal calf serum substitute. J Cell Physiol. 2007;211:121-130.

38. Fekete N, Gadelorge M, Furst D, et al. Platelet lysate from whole bloodderived pooled platelet concentrates and apheresis-derived platelet concentrates for the isolation and expansion of human bone marrow mesenchymal stromal cells: production process, content and identification of active components. Cytotherapy. 2012;14:540-554.

39. Fossett E, Khan WS. Optimising human mesenchymal stem cell numbers for clinical application: a literature review. Stem Cells Int. 2012;2012:465259. 
40. Santos F, Andrade PZ, Abecasis MM, et al. Toward a clinicalgrade expansion of mesenchymal stem cells from human sources: a microcarrier-based culture system under xeno-free conditions. Tissue Eng Part C Methods. 2011;17:1201-1210.

41. Khanal S, Tomlinson A. Tear physiology in dry eye associated with chronic GVHD. Bone Marrow Transplant. 2012;47:115-119.

42. Krampera M, Galipeau J, Shi Y, Tarte K, Sensebe L. Immunological characterization of multipotent mesenchymal stromal cells - The International Society for Cellular Therapy (ISCT) working proposal. Cytotherapy. 2013;15:1054-1061.

43. Prockop DJ. Defining the probability that a cell therapy will produce a malignancy. Mol Ther. 2010;18:1249-1250.

44. Casiraghi F, Remuzzi G, Abbate M, Perico N. Multipotent mesenchymal stromal cell therapy and risk of malignancies. Stem Cell Rev. 2013;9: 65-79.

45. von Bahr L, Batsis I, Moll G, et al. Analysis of tissues following mesenchymal stromal cell therapy in humans indicate limited long-term engraftment and no ectopic tissue formation. Stem Cells. 2012;30: 1575-1578.

46. Lucchini G, Dander E, Pavan F, et al. Mesenchymal stromal cells do not increase the risk of viral reactivation nor the severity of viral events in recipients of allogeneic stem cell transplantation. Stem Cells Int. 2012;2012:690236.

47. Meisel R, Brockers S, Heseler K, et al. Human but not murine multipotent mesenchymal stromal cells exhibit broad-spectrum antimicrobial effector function mediated by indoleamine 2,3-dioxygenase. Leukemia. 2011;25:648-654

48. Wang J, Liao L, Wang S, Tan J. Cell therapy with autologous mesenchymal stem cells - how the disease process impacts clinical considerations. Cytotherapy. 2013;15:893-904.

49. Le Blanc K, Rasmusson I, Sundberg B, et al. Treatment of severe acute graft-versus-host disease with third party haploidentical mesenchymal stem cells. Lancet. 2004;363:1439-1441.

50. Le Blanc K, Frassoni F, Ball L, et al. Mesenchymal stem cells for treatment of steroid-resistant, severe, acute graft-versus-host disease: a phase II study. Lancet. 2008;371:1579-1586.

51. ClinicalTrials.Gov. Efficacy and safety of adult human mesenchymal stem cells to treat steroid refractory acute graft versus host disease. Osiris Therapeutics. Available from: http://www.clinicaltrials.gov/ct2/ show/NCT00366145?term=mesenchymal+stem+cells+AND+bone+m arrow+transplantation\&rank=16. Accessed December 22, 2013.

52. Galipeau J. The mesenchymal stromal cells dilemma-does a negative phase III trial of random donor mesenchymal stromal cells in steroidresistant graft-versus-host disease represent a death knell or a bump in the road? Cytotherapy. 2013;15:2-8.

53. Kuzmina LA, Petinati NA, Parovichnikova EN, et al. Multipotent mesenchymal stromal cells for the prophylaxis of acute graft-versushost disease - a Phase II study. Stem Cells Int. 2012;2012:968213.

54. Yang YG, Wang H, Asavaroengchai W, Dey BR. Role of interferongamma in GVHD and GVL. Cell Mol Immunol. 2005;2:323-329.

55. Krampera M, Cosmi L, Angeli R, et al. Role for interferon-gamma in the immunomodulatory activity of human bone marrow mesenchymal stem cells. Stem Cells. 2006;24:386-398.

56. Krampera M. Mesenchymal stromal cell 'licensing': a multistep process. Leukemia. 2011;25:1408-1414.
57. Zhou H, Guo M, Bian C, et al. Efficacy of bone marrow-derived mesenchymal stem cells in the treatment of sclerodermatous chronic graft-versus-host disease: clinical report. Biol Blood Marrow Transplant. 2010;16:403-412.

58. Weng J, He C, Lai P, et al. Mesenchymal stromal cells treatment attenuates dry eye in patients with chronic graft-versus-host disease. Mol Ther. 2012;20:2347-2354.

59. Prockop DJ, Brenner M, Fibbe WE, et al. Defining the risks of mesenchymal stromal cell therapy. Cytotherapy. 2010;12:576-578.

60. Menard C, Pacelli L, Bassi G, et al. Clinical-grade mesenchymal stromal cells produced under various good manufacturing practice processes differ in their immunomodulatory properties: standardization of immune quality controls. Stem Cells Dev. 2013;22:1789-1801.

61. Fox JM, Chamberlain G, Ashton BA, Middleton J. Recent advances into the understanding of mesenchymal stem cell trafficking. Br J Haematol. 2007; 137:491-502.

62. Yagi H, Soto-Gutierrez A, Parekkadan B, et al. Mesenchymal stem cells: mechanisms of immunomodulation and homing. Cell Transplant. 2010;19:667-679.

63. Herrmann R, Sturm M, Shaw K, et al. Mesenchymal stromal cell therapy for steroid-refractory acute and chronic graft versus host disease: a phase 1 study. Int J Hematol. 2012;95:182-188.

64. Forbes GM, Sturm MJ, Leong RW, et al. A Phase 2 study of allogeneic mesenchymal stromal cells for luminal Crohn's disease refractory to biologic therapy. Clin Gastroenterol Hepatol. 2014;12:64-71.

65. Ringden O, Uzunel M, Rasmusson I, et al. Mesenchymal stem cells for treatment of therapy-resistant graft-versus-host disease. Transplantation. 2006;81:1390-1397.

66. Fang B, Song Y, Liao L, Zhang Y, Zhao RC. Favorable response to human adipose tissue-derived mesenchymal stem cells in steroidrefractory acute graft-versus-host disease. Transplant Proc. 2007;39: 3358-3362.

67. von Bonin M, Stolzel F, Goedecke A, et al. Treatment of refractory acute GVHD with third-party MSC expanded in platelet lysate-containing medium. Bone Marrow Transplant. 2009;43:245-251.

68. Kebriaei P, Isola L, Bahceci E, et al. Adult human mesenchymal stem cells added to corticosteroid therapy for the treatment of acute graft-versus-host disease. Biol Blood Marrow Transplant. 2009;15: 804-811.

69. Perez-Simon JA, Lopez-Villar O, Andreu EJ, et al. Mesenchymal stem cells expanded in vitro with human serum for the treatment of acute and chronic graft-versus-host disease: results of a phase I/II clinical trial. Haematologica. 2011;96:1072-1076.

70. Muroi K, Miyamura K, Ohashi K, et al. Unrelated allogeneic bone marrow-derived mesenchymal stem cells for steroid-refractory acute graft-versus-host disease: a phase I/II study. Int J Hematol. 2013;98: 206-213.

71. Zhang LS, Liu QF, Huang K, Zhang Y, Fan ZP, Huang SL. [Mesenchymal stem cells for treatment of steroid-resistant chronic graft-versus-host disease]. Zhonghua Nei Ke Za Zhi. 2009;48:542-546. Chinese.

72. Weng JY, Du X, Geng SX, et al. Mesenchymal stem cell as salvage treatment for refractory chronic GVHD. Bone Marrow Transplant. 2010;45:1732-1740.
Stem Cells and Cloning: Advances and Applications

\section{Publish your work in this journal}

Stem Cells and Cloning: Advances and Applications is an international, peer-reviewed, open access journal. Areas of interest in stem cell research include: Embryonic stem cells; Adult stem cells; Blastocysts; Cordblood stem cells; Stem cell transformation and culture; Therapeutic cloning; Umbilical cord blood and bone marrow cells; Laboratory,

\section{Dovepress}

animal and human therapeutic studies; Philosophical and ethical issues related to stem cell research. This journal is indexed on CAS. The manuscript management system is completely online and includes a quick and fair peer-review system. Visit http://www.dovepress.com/ testimonials.php to read real quotes from published authors. 